\title{
POTENSI ARKEOLOGI KOLONIAL DI MALUKU DAN SASARAN UTAMA PENELITIANNYA
}

\author{
G.M. Sudarmika
}

\section{Pendahuluan}

Penelitian yang telah dilaksanakan oleh Balai Arkeologi Ambon belum dapat mencakup seluruh wilayah kerja Balai Arkeologi Ambon yang meliputi Propinsi Maluku dan Maluku Utara. Sejak Balai Arkeologi Ambon berdiri tahun 1995 telah melakukan penelitian di beberapa tempat di antaranya adalah Ternate, Tidore, Kayoa (Maluku Utara), Seram, Buru, Saparua (maluku Tengah) dan Tual, Saumlaki (Maluku Tenggara).

Dari hasil-hasil penelitian tersebut sebagian besar datanya berupa tinggalan masa kolonial misalnya, benteng, loji, rumah tahanan, istana mini, rumah pengasingan dan lain sebagainya. Tinggalantinggalan kolonial yang dimaksud ada yang sudah dipugar adapula yang belum pernah disentuh sama sekali. Khususnya tinggalan benteng keberadaannya hampir tersebar di setiap pulau yang ada di Maluku.

Melihat karateristik tinggalan arkeologi yang tersebar di seluruh wilayah Maluku berupa tinggalan kolonial dengan tidak mengesampingkan terhadap data tinggalan budaya lainnya, maka penelitian-penelitian yang mengacu pada hasil karya budaya kolonial yaitu sejak masuknya bangsa asing di Maluku akan lebih diintensifkan. Selanjutnya kegiatan ini akan dijadikan program unggulan oleh Balai Arkeologi Ambon.

\section{Sekilas Tentang Maluku Sejak Masuknya Bangsa Asing}

Selama berabad-abad kepulauan Maluku merupakan ajang persaingan sengit antara bangsa Asia dan Eropa dalam memperebutkan cengkeh dan pala yang merupakan komoditi utama pada waktu itu yang harganya sangat mahal. Para pedagang Portugis, Spanyol, Inggris 
dan Belanda yang mencari kemasyuran, keuntungan dan kekuasaan terlibat dalam persaingan sengit bukan hanya antara mereka melainkan pula dengan dari Arab, India, Cina, Jawa dan Makasar, serta orang dari Maluku sendiri.

Bangsa asing yang pertama kali menginjakkan kakinya di Maluku khususnya Maluku Tengah adalah Portugis yaitu di Kepulauan Banda sekitar tahun 1512, dimana pelaut-pelaut Portugis dibantu oleh mualim-mualim Melayu yang memandu jalan lewat Jawa, Kepulauan Sunda Kecil dan sampai di perairan Maluku. Di tempat inilah pelautpelaut Portugis melakukan transaksi perdagangan dengan penduduk asli Banda, berupa buah dan bunga pala serta cengkeh. Portugis sebenarnya lebih berminat kepada Ternate dan Tidore sehingga Pulau Banda diabaikan, hanya sekali-sekali saja Armada Portugis berlayar tiap tahun dari Gowa lewat Malaka kemudian singgah di Banda untuk mengangkut pala atau hanya sekedar menanti angin reda yang bertentangan arah sambil mengambil makanan dan air. Pada waktu Kapten Garcias mengadakan parade tentara di Banda, mereka mulai membangun sebuah benteng di Pulau Neira (Banda) tetapi tidak diteruskan. Setelah kedatangan Portugis baru kemudian disusul oleh bangsa lainnya yaitu Belanda, Inggris dan Spanyol.

Dari sekian bangsa asing yang masuk ke wilayah Maluku hanya Belandalah yang paling berhasil menanamkan pengaruhnya baik dibidang poltik, ekonomi, budaya dan agama. Belanda yang muncul diperairan Maluku abad ke 16 mendapatkan tiga kekuasaan yang sedang saling berperang untuk merebut hegomoni atas kepulauan rempah-rempah (Maluku). Kesultanan Ternate sedang berperang melawan kesultnanan Tidore, sementara Ternate telah berhasil mengusir Portugis untuk mundur dari Ternate dan bercokol di Ambon (1575).

Kekuasaan Belanda yang berwujud dalam VOC atau Kompania Wolanda, terjun dalam pergolakan perebutan kekuasaan dan berhasil mengusir Portugis dari Maluku (1605). Kemudian mulailah berperang dengan perebutan gudang rempah-rempah antara Belanda dengan para sultan di Maluku Utara, Inggris, Spanyol dan raja-raja di Maluku
Tengah. Pada pertengahan abad ke - 17 sekitar tahun 1650, Belanda telah berhasil membulatkan kekuasaannya di Maluku sesudah mengalahkan dan menghalaukan pesaingnya yaitu Portugis dan Inggris berturutturut di Ambon, Ternate, Bacan dan Banda, menaklukkan pedagangpedagang Indonesia di Maluku dan mengadakan kontrak-kontrak yang mengikat sultan-sultan dan raja-raja di seluruh Maluku.

Dengan jalan mengikat raja-raja dan para sultan dengan perjanjian (kontrak) sebagai kunci monopoli dan ekspedisi-ekspedisi hongi, maka kebebasan rakyat dalam perekonomian terancam. Perkebunan cengkeh di Maluku Utara (pulau Ternate, Tidore dan Makian) ditiadakan dan dikonsentrasikan di Pulau Ambon dan Kepulauan Lease, sedangkan untuk perkebunan pala dikonsentrasikan di Kepulauan Banda. Usaha Kompeni Belanda untuk memperoleh hakhak monopoli mendesakkan pengaruhnya kepada penguasa-penguasa bumiputera. Kekuatan militer Belanda yang mengikuti perahu-perahu Kompeni dipakai untuk menakut-nakuti ataupun untuk mendesakkan tuntutannya kepada penguasa-penguasa bumiputera, sehingga lambat laut dapat dikuasainya.

Untuk mendapatkan keuntungan-keuntungan sebanyakbanyaknya dalam perdagangan rempah-rempah itu Belanda melakukan tindakan-tindakan yang sangat memberatkan hati rakyat. Perintah penebangan pohon - pohon cengkeh apabila cengkeh dipasaran harganya menurun dan menanam kembali secara serentak apabila harga cengkeh mulai meningkat. Beban lain yang dipikulkan oleh rakyat adalah sistem penyerahan wajib hasil rempah-rempah kepada kompeni. Sistem ekstirpasi atau pemusnahan kelebihan pohon cengkeh dan pala di pulau-pulau tersebut dan tempat-tempat lainnya dengan jalan ekspedisi hongi membawa kesengsaraan yang sangat mendalam bagi rakyat. Perdagangan dan pelayaran rakyat dimusnahkan dengan jalan memblokade terhadap pedagang-pedagang rakyat. Armada pengangkutan rakyat dimusnahkan, sedangkan Kompeni Belanda dengan gencarnya melaksanakan monopoli produksi, perdagangan, pelayaran (pengangkutan), yang kesemuanya itu dapat mengundang peperangan secara besar-besaran selama suatu periode yang panjang. 
Begitulah kurang lebihnya kondisi di Maluku pada saat berlangsungnya kekuasaan bangsa asing. Dengan itikad untuk menguasai seluruh tatanan kehidupan masyarakat Maluku utamanya di bidang perekonomian dan politik tentunya mereka akan menggunakan segala macam cara untuk mencapai maksud tersebut baik secara damai maupun dengan kekerasan (perang). Sebagai negara yang maju tentunya kondisi tersebut telah dipersiapkan terlebih dahulu misalnya dengan pendirian benteng-benteng, istana (rumah tinggal), persenjataan dan lain sebagainya. Sehingga sampai sekarang data-data sejarah tersebut masih dapat kita saksikan di hampir seluruh wilayah Maluku.

\section{Potensi Tinggalan Kolonial}

Dari hasil survei yang telah dilaksanakan selama ini oleh Balai Arkeologi Ambon tinggalan kolonial yang telah diinventarisasi adalah :

a. Untuk wilayah Maluku Utara antara lain :

- Benteng Oranye

- Benteng Toluko

- Benteng Kalamata

- Benteng Santo Pedro E' Paulo

b. Untuk wilayah Maluku Tengah antara lain :

- Benteng Nassau

- Benteng Revenge

- Benteng Hollandia

- Loji Lonthor

- Benteng Selandia Baru

- Gereja Tua Banda

c. Untuk wilayah Maluku Tenggara antara lain :

- Benteng Delehaven

- Benteng Wokam

- Gereja Tua Kisar
Tinggalan kolonial tersebut di atas sebagaian besar belum dipugar dengan kondisi rata-rata 60-70\% dalam kondisi baik, tapi ada juga tinggalan yang tinggal hanya pondasinya saja misalnya Loji Lonthor di Banda (Maluku Tengah) dan Benteng Wokam di Dobo (Maluku Tenggara).

\section{Arah dan Sasaran Program Unggulan}

Dengan melihat potensi kepurbakalaan terutama masa kolonial yang ada di wilayah kerja Balai Arkeologi Ambon, maka program unggulan dibidang kolonial sasarannya perlu diarahkan sehingga kegiatan program unggulan dapat berhasil dan berdayaguna, terutama dalam memupuk dan meningkatkan rasa persatuan dan kesatuan, membangun karakter bangsa (national character building) serta dapat mengembangkan kesadaran akan perjalanan sejarah bangsa dalam mengadapi kondisi bangsa di era krisis multidimensional yang sampai saat sekarang masih dirasakan.

Berkaitan dengan program unggulan dan harapan yang dicanangkan oleh Balai Arkeologi Ambon itu maka arah dan sasaran dari program unggulan tersebut secara rinci akan dituangkan kedalam program jangka pendek dan jangka panjang.

\section{Program Jangka Pendek}

a. Mendata tinggalan kolonial di seluruh wilayah Maluku Tengah yang meliputi; P. Seram, P. Saparua, P. Nusalaut, P. Haruku. P. Gorong, Kep. Banda dan lain sebagainya.

b. Mendata tinggalan kolonial di seluruh wilayah Maluku Tenggara yang meliputi; Kep. Maluku Tenggara Barat, Kep. Maluku Selatan Daya. Kep. Aru, Leti, Moa, Lakor, P. Kisar, P. Tanimbar, P. Selaru dan lain sebagainya.

c. Menelusuri sejarah dan keberadaannya tinggalan tersebut pada masa lampau.

d. Pembuatan data base dalam program SIKT (Sistem Informasi Kebudayaan Terpadu).

e. Menentukan skala prioritas untuk penelitian yang lebih intensif. 


\section{II.Program Jangka Panjang}

a. Semua data tinggalan kolonial telah terinvetarisasi yang meliputi seluruh wilayah Provinsi Maluku dan Maluku Utara, baik dalam bentuk foto, gambar, maupun komputerisasi data base dalam jaringan SIKT.

b. Membuat peta tinggalan kolonial yang mencakup seluruh wilayah Maluku.

c. Pembuatan peta zonasi tinggalan kolonial berdasarkan perjalanan sejarah masing-masing wilayah yang untuk sementara dapat dibagi empat zona yaitu Z-1 Ternate-Tidore, Z-2 Banda, Z-3 Ambon dan Z-4 Lease.

d. Menentukan kronologi dan perjalanan sejarah Maluku mulai dari pendudukan bangsa asing sampai masa kemerdekaan.

\section{Penutup}

Program unggulan Balai Arkeologi Ambon di bidang kolonial akan diimplementasikan melalui kegiatan penelitian yang intensif terhadap tinggalan-tinggalan masa kolonial di Maluku yang masih dapat diamati sampai sekarang. Dengan keterbatasan tenaga dan sarana yang ada, dan untuk mencapai sasaran yang telah dituangkan kedalam program jangka pendek dan jangka panjang itu, maka Balai Arkeologi Ambon akan memaksimalkan potensi yang ada dengan berkerja sama dengan perguruan tinggi (FKIP UNPATI), Masyarakat Sejarawan Indonesia (MSI) Cabang Maluku dan instansi terkait lainnya.

Dengan demikian harapan yang hendak dicapai dalam kegiatan tersebut adalah hendaknya seluruh masyarakat Maluku Khususnya dan Indonesia umumnya mengetahui, mengerti dan memahami bahwa tinggalan budaya kolonial tersebut pada dasarnya mempunyai makna yang dalam dan dapat memberikan kontribusi yang nyata dalam pembangunan manusia Indonesia seutuhnya baik masa sekarang maupun di masa yang akan datang.

\section{DAFTAR PUSTAKA}

Abdurrachman Paramita R. 1973,

Bunga Rampai Sejarah Maluku (1), Lembaga Penelitian Sejarah Maluku, Jakarta.

Frans, Rijoli, 1994,

Buah Emas Dari Banda, Laporan Survey Pengadaan, Museum Negeri Siwalima-Ambon.

Hanna A. Wilard, 1983,

Indonesia Banda, a Publication of Institute for the Study of Human.

Hanna A. Willard \& Des Alwi, 1996,

Ternate dan Tidore Masa Lalu Penuh Gejolak, Pusat Sinar Harapan, Jakarta.

Hasil-Hasil Penelitian Balai Arkeologi Ambon. 